\title{
THE EFFECTIVENESS OF INTRADIALYSIS STATIC BIKE EXERCISE TOWARD FUNCTIONAL CAPACITY IN HEMODIALYSIS PATIENTS
}

\author{
Ria Desnita ${ }^{1^{*}}$, Vivi Syofia Sapardi ${ }^{1}$ \\ ${ }^{1}$ Nursing Study Program STIKES MERCUBAKTIJAYA Padang, West Sumatera, Indonesia \\ *Correspondence: \\ Ria Desnita \\ Email: ria.desnita18@gmail.com \\ Address: STIKES MERCUBAKTIJAYA Padang, Surau Gadang, Nanggalo, Padang City, West Sumatra 25173
}

\begin{abstract}
Background: Patients with terminal renal failure require renal replacement therapy in the form of hemodialysis. Although already have hemodialysis therapy, there is still buildup of metabolic waste in patients' body that results in a decrease in functional capacity. Decreased functional capacity in hemodialysis patients causes limitations in carrying out physical activities that reduces their quality of life. However, intradialysis physical exercise by using static bike can be a therapy to increase patients' functional capacity.

Objective: This study was aimed to determine the effectiveness of static bike exercise toward functional capacity in hemodialysis patients.

Method: This research is a quantitative study with a quasi-experimental method using pre and post approach with control group design. Intervention and control groups were included in this study. There were 20 people in each group that were selected through consecutive sampling technique as samples of this study. The study was carried out in the hemodialysis room of RSUP Dr. M. Djamil, Padang.

Result: The analysis was done using Paired T-Test with a degree of confidence of $95 \%$ and showed that intradialysis static bike exercise effectively increased the functional capacity in hemodialysis patients $(\mathrm{p}=0.001)$.

Conclusion: Intradialysis static bike exercise can be used as a nursing intervention to increase the functional capacity in hemodialysis patients.
\end{abstract}

Key words: Hemodialysis, exercise, functional capacity.

\section{INTRODUCTION}

Patients with terminal renal failure need renal replacement therapy to prolong their life span (Sukandar, 2013). The most commonly used renal replacement therapy is hemodialysis. Hemodialysis replaces kidney function to filter blood by removing metabolic waste and water through a dializer (O'Callagan, 2009). However, hemodialysis is not a cure for kidney failure because some metabolic and endocrine activities of the kidney cannot be replaced, so the patients continues to experience symptoms and effects of the disease and the therapy they undergo (Sukandar, 2013)

Irreversible renal damage causes a buildup of metabolic waste in the body that causes disorders such as fatigue, thought disorder, and increased heart workload which ultimately result in decreased functional capacity (Jha et al., 2013) Functional capacity is the ability of individuals to carry out their daily activities adequately (Pollentier \& Irons, 2012). Decreased functional capacity in 
hemodialysis patients causes limitations in carrying out physical activities that reduces their quality of life. From the evaluation of functional capacity in 108 patients with renal failure using a 6-minute walking test, it is showed that half of the patients had decreased functional capacity (Barril, Nogueira, Alvarez, \& SanhezTomero, 2018)

Increased functional capacity will improve patients' ability to do activities independently and meaningfully (Pollentier \& Irons, 2012). One of the efforts that can be made to increase the functional capacity in hemodialysis patients is doing intradialysis physical exercise by using static bike. This exercise is effective to do when having dialysis for it only involves leg movement. When having hemodialysis, the vascular access is attached to the upper limb. Physical exercise is effective to optimize limb muscle function, improve blood flow and increase the heart pump (Malagoni et al., 2008). Intradialysis physical exercise causes dilation of blood vessels due to the relaxation and contraction of muscles during exercise and increase the capacity of vascular volume in delivering metabolic waste to the hemodialysis machine so that the cleaning is optimal (Jung \& Park, 2011)

On the other hand, intradialysis physical exercise has not been widely applied and does not get adequate attention from patients. Therefore, most of them only lie in sleeping position during hemodialysis. Several studies have examined the effectiveness of intradialysis physical exercise, but there have been no studies examining the effectiveness of static bike exercise on the functional capacity in hemodialysis patients. Moreover, some previous studies only focused on the effect of exercise on decreasing ureum levels and hemodialysis adequacy. The limited results of research on intradialysis physical exercise makes nurses unable to carry out their roles as counselors and educators for hemodialysis patients to do intradialysis exercises.

\section{METHODS}

Study Design

This research is a quantitative study with a quasi-experimental method using pre and post approach with control group design. Intervention and control groups were included in this study. Intervention group is the group of respondents who did static bike exercise during hemodialysis therapy, while control group was designed to make comparison that the samples did not receive treatment.

\section{Setting}

This research was carried out in the hemodialysis room of RSUP Dr. M. Djamil, Padang.

\section{Research Subject}

The sampling was done through nonprobability sampling technique with consecutive sampling. The inclusion criteria of this study are respondents who are willing to participate in this study, patients undergoing routine hemodialysis, patients aged > 18 years, patients with hemoglobin level $>8 \mathrm{gr} / \mathrm{dl}$, and patients with stable hemodynamic. Furthermore, the exclusion criteria include musculoskeletal disorder that affects the mobilization activities and patients with respiratory failure. Each intervention and control group had 20 people as samples that were selected through consecutive sampling technique.

\section{Instruments}

The intervention variable of this study is intradialysis static bike exercise, while the independent variable is functional capacity. Functional capacity was measured by 6 minutes' walk test. 


\section{Data Analysis}

The analysis was done to see the effect of intradialysis static bike exercise on functional capacity. The test used was paired test because the data is normally distributed.

\section{Ethical Consideration}

This research has gone through an ethical test and obtained permission from STIKes MERCUBAKTIJAYA Padang with license number 344/LP2M/STIKesMCB/VII/2019 and RSUP Dr. M. Djamil Padang with license number DL.01.03.07.2099

\section{RESULTS}

Functional Capacity Overview Before and After the Intervention

The functional capacity in hemodialysis patients in the intervention and control groups, before and after the implementation of intradialysis static bike exercise intervention, can be seen in the following table.

Table 1. Functional Capacity Distribution Before and After Intradialysis Static Bike Exercise in Intervention and Control Groups $(n=20)$.

\begin{tabular}{llccc}
\hline Group & Measurement & n & Mean \pm SD & Min-Max \\
\hline \multirow{2}{*}{ Intervention } & Before & 20 & $233.00 \pm 12.98$ & $210-256$ \\
& After & 20 & $240.35 \pm 14.77$ & $210-270$ \\
\hline \multirow{2}{*}{ Control } & Before & 20 & $230.80 \pm 14.59$ & $205-253$ \\
& After & 20 & $230.05 \pm 13.87$ & $205-253$ \\
\hline
\end{tabular}

Source: Primary data of questionnaire, 2019

From the table above, the average functional capacity before and after the treatment in the intervention group was 233 and 240.35 , respectively. On the other hand, in the control group, the mean value of functional capacity before and after treatment were 230.80 and 230.05, respectively.

\section{Differences in Functional Capacity Before and After the Treatment}

The effectiveness of intradialysis static bike exercise on functional capacity in hemodialysis patients can be seen based on the result of the differences in functional capacity before and after the treatment in intervention and control groups using paired T-test in the following table.

Table 2. Differences in Functional Capacity Before and After Intradialysis Static Bike Exercise in Intervention and Control Groups $(\mathrm{n}=20)$.

Based on the table above, the intervention group showed an increase in functional capacity after having the treatment of static bicycle exercise. This means that intradialysis static bike exercise was effective in increasing functional capacity in hemodialysis patients in the intervention group $(p=0.001)$. On the other hand, there was no difference in functional capacity before and after treatment in the control group ( $p=0.575)$.

\section{DISCUSSION}

From the study, it was found that the average functional capacity of the intervention group had increased by 7.35 meters based on the measurement before and after intradialysis static bike exercise was carried out. This is because physical exercise provides benefits for patients by optimizing limb muscle function, improving blood flow and increasing the effectiveness of heart pumps (Mallagoni et al., 2008). Physical exercise also facilitates oxygen transport, thereby increasing the number of red blood cells. Intradialysis static bike exercise is one of the activities 
that patients can do to improve their muscle strength, mental and physical function and dialysis efficiency. Doing physical exercise during dialysis can increase blood flow to the muscles so that it gives vasodilation effect on blood vessels. This process will increase urea and creatinine regulation from intracellular to vascular which then flowed to the dializer. The more urea removed from the body, the less symptoms of uremia in patients. Thus, it reduces the level of fatigue in patients and increases their functional capacity (Maja, Cuk, \& Bojan, 2016). Some previous studies showed that there was a decrease of urea in hemodialysis patients given intradialysis static bike exercise and increase of hemodialysis adequacy that gave an impact on the increase of functional capacity in patients (Parsons, Tosselmire, \& King-VanVlack, 2006)

Parsons, Teoffelmere, \& King (2004) stated that intradialysis ergometry exercise performed for 15 minutes in the first 3 hours of dialysis increased the adequacy of hemodialysis. Furthermore, this exercise is recommended for hemodialysis patients. They also stated that intradialysis physical exercise can improve hemodialysis adequacy and physical function in hemodialysis patients, where the exercise was carried out for 30 minutes in the first 2 hours of hemodialysis. In addition, physiological, psychological and musculoskeletal changes due to physical exercise were also reported to increase functional capacity. Increased functional capacity will increase patients' ability to do activities independently and meaningfully. Some research suggested that physical exercise can minimize symptoms, increase exercise tolerance, improve quality of life and provide a satisfying effect on patient recovery. Physical exercise is proven to increase exercise capacity, self-efficacy, and reduce the number of readmission (Jung \& Park, 2011).

\section{CONCLUSION}

According to the results of the study, it was found out that intradialysis static bike exercise is effective in increasing the functional capacity in hemodialysis patients.

\section{SUGGESTIONS}

Intradialysis static bike exercise can be used as a nursing intervention in performing nursing care for patients with chronic renal failure undergoing hemodialysis.

\section{ACKNOWLEDGMENT}

A big thanks from researchers to Kemenristek Dikti, who have supported this research, to STIKes MERCUBAKTIJAYA Padang dan RSUP Dr. M. Djamil Padang who have given permission for this research and supported the researcher to conduct this research.

\section{DECLARATION OF CONFLICTING INTEREST}

No potential conflict of interest was reported by the authors.

\section{FUNDING}

This research funding comes from the Ministry of Research, technology and Higher Education in National competitive research which is only in the beginner lecturer research in 2018.

\section{AUTHOR CONTRIBUTION}

Ria Desnita: Prepare research proposal, conducting, research permit, selecting samples based on inclusions and exclusions criteria, intervening static bike exercise, compile research report, writing manuscript and presentation result report.

Vivi Syofia Sapardi: Assist in preparing proposal, collecting pre and post test data, perform data processing, analyses data, assist in the preparation of publication. 
ORCID

Ria Desnita

None.

Vivi Syofia Sapardi

None.

\section{REFERENCES}

Barril, G., Nogueira, A., Alvarez, G., \& Sanhez-Tomero, J.A. (2018). Evaluation of functional capacity through the 6 minutes walking test (6MWT) in patients with CKD. Ann Nutr Disord \& Ther, 5(1), 1053.

Jha, V., Garcia-Garcia, G., Iseki, K., Li, Z., Plattner, B., Saran, R., Wang, A. Y., \& Yang, C. W. (2013). Chronic kidney disease: global dimension and perspective. Lancet, 20(382), 260 272.

Jung, T.D, \& Park, S.H. (2011). Intradialytic exercise programs for hemodialysis patients. Chonnam Med $J, 47(2), 61-65$.

O'Callaghan, Chris. (2009). At a glance sistem ginjal. Jakarta: Penerbit Erlangga.

Malagoni, A.M., et all. (2008). Acute and long-term effects of an exercise program for dialysis patients prescribed in hospital and performed at home. Journal of Nephrology, 21(6), 871-878.

Maja, B., Cuk, I., \& Bojan, L. (2016). Sixminute walk test in renal failure patients: Representative result, performance analysis and perceived fatique predictors. Plos One. Doi: 10.1371/journal.pone.0150414

Makhlough, A., Ilali, E., Mohseni, R., \& Shahmohammadi, S. (2012). Effect of intradialytic aerobic exercise on serum electrolytes levels in hemodialysis patients. Iranian Journal of Kidney Disease, 6(2), 119123.

Parsons, T.K., Tosselmire, E.D., KingVanVlack, C.E. (2006). Exercise training during hemodialysis improves dyalisis efficacy and physical performance. Exercise Arch Phys Med Rehabil, 87, 680-687.

Parsons, T.L., Tosselmire, E.D., KingVanVlack, C.E. (2004). The effect of an exercise program during hemodialysis on dialysis efficacy, blood pressure and quality of life in end stage renal disease (ESRD) patients. Clinical Nephrology, 61(4), 261-274

Pollentier, B. \& Irons, S. (2012). Examination of the six-minute walk test to determine functional capacity in people with chronic kidney disease. Kidney Inter Suppl. 2, 279-334. Doi: 10.1038/kisup.2012.40

Sukandar, Enday. (2013). Nefrologi klinik. Bandung: Pusat Informasi Ilmiah.

Cite This Article As: Desnita, R., \& Sapardi, V.S. The Effectiveness of Intradialysis Static Bike Exercise toward Functional Capacity in Hemodialysis Patients. Nurse and Health: Jurnal Keperawatan 2019; 8(2): $78-82$. 